\title{
MENGELOLA MANAJEMEN LOGISTIK DENGAN EFEKTIF DI UNIVERSITAS NEGERI SEMARANG
}

\author{
Wisudani Rahmaningtyas ${ }^{1 *}$, Ismiyati ${ }^{2}$, Hengky Pramusinto ${ }^{3}$ \\ Universitas Negeri Semarang, Gunungpati, 50229, Semarang, Indonesia
}

\begin{abstract}
This research aims at analyzing the logistic management and examining the arising problems faced when managing the logistics at economics faculty of Semarang state university. Logistics is one essential administration that should be made by an organization. The logistic procedures consist of procurement, recording, storage, distribution, maintenance, and elimination. At present, the logistic activities at economics faculty are running quite well. However, based on the studies conducted by many researchers, the logistic impacts require further examination and analysis. The pre-research study based on interviews shows that no logistic staff handles the logistic management. For the time being, the logistic activities are handled by the public utility staffs. Besides, the Standardized Operational Procedures on logistic management are still unclear.This research uses a descriptive-qualitative approach. Data are obtained from informants in the forms of words, measures, and writings. Interview, observation, and documental analysis are techniques used to collect the data. Samples are taken with a purposive sampling technique and then data are analyzed using an interactive technique. Data validation is conducted using triangulation techniques and methodologies. The research results show that the logistic activities are not yet ideally running, such as poor conditioned inventory management of goods, uncontrolled stock opname; not maximally utilized forms as the controlling devices; limited warehouses for supply storage; unavailable warehouses for storage of the upcoming goods to eliminate, unscheduled goods inventory maintenance, and too long waiting period of elimination activities.
\end{abstract}

Keywords : administration, management, logistics, logistic management, organization

\section{PENDAHULUAN}

Kompleksitas aktivitas dalam organisasi menuntut para penggerak roda kehidupan organisasi untuk berkerja keras pada tiap-tiap spesialisasi pekerjaannya. Kegiatan manajemen perlu dikembangkan dan dikelola dengan baik guna ketercapaian tujuan lembaga dan menguatkan visi misi yang dirumuskan. Sejalan dengan visi misi yang diusung Fakultas Ekonomi untuk memberikan pelayan prima. Untuk itu penguatan pada aktivitas yang dijalankan didalamnya sangat diperlukan. Salah satu aktivitas yang perlu dikuatkan adalah pelayanan pada pengelolaan perbekalan kantor. Perbekalan kantor dalam perkembangannya dikenal dengan banyak istilah yaitu administrasi perbekalan, manajemen barang, administrasi barang, dan manajemen logistik. Beebrapa istilah tersebut memiliki satu arti yaitu tentang pengelolaan perbekalan atau logistik pada suatu organisasi. Perbekalan sendiri condong pada kegiatan mengperbekalankan barang, baik itu barang habis pakai maupun barang yang tidak habis pakai, perlengkapan kantor maupun peralatan kantor. Ketersediaan barang perbekalan kantor menentukan kelancaran aktivitas pekerjaan baik tenaga pendidikan dan kependidikan. Sementara tujuan yang hendak dicapai dalam setiap kegiatan pengelolaan logistik adalah mampu mendukung efektivitas dan 
efisiensi dalam setiap upaya pencapaian tujuan organisasi (Lukas Dwiantara, 2004:2).

Ketepatan dan keakuratan dalam pengelolaan perbekalan menjadi kunci keberhasilan untuk tertib administrasi perbekalan itu sendiri. Pengelolaan perbekalan secara adiminstratif strategik terurai dalam serangkaian kegiatan administrasi, dimulai dari perencanaan, pengorganisasian, dan pengawasan. Disamping itu untuk kegiatan operasionalnya terdiri dari pengadaan, pencatatan, pendistribusian, penyimpanan, pemeliharaan dan penghapusan (Lukas Dwiantara, 2004:2). Dengan demikian pengelolaan perbekalan harus memperhatikan kegiatan operasional perbekalan. Dimana setiap tahapannya harus dilakukan, guna kelancaran tertib perbekalan di suatu organisasi. Sementara Richardus Eko (2005:4) menyatakan bahwa "manajemen persediaan adalah kegiatan yang berhubungan dengan perencanaan, pelaksanaan dan pengawasan penentuan kebutuhan material sedemikian rupa". dari definisi tersebut tersirat dengan jelas bahwa kegiatan pengelolaan perbekalan bertujuan untuk menjamin ketersediaan barang-barang inventaris, membatasi nilai, jenis dan jumlah barang serta memanfaatkan seoptimal mungkin barang atau material yang sudah tersedia.

Fakultas Ekonomi Universitas Negeri Semarang merupakan instansi pendidikan tinggi, yang mana rotasi barang berputar sangat cepat sehingga diperlukan tenaga profesional yang tepat dan memiliki cukup pengetahuan tentang pengelolaan barang. Kegiatan tersebut adalah kegiatan perbekalan kantor, dimana dalam mengadakan barang hingga penghapusan barang didalamnya terdapat kegiatan perencanaan, pengorganisasian dan pengawasan.
Kegiatan pengelolaan perbekalan terdiri dari kegiatan pengadaan dimana pihak pengelola perbekalan menyediakan logistik sesuai dengan kebutuhan, baik berkaitan dengan spresifikasi, jumlah, waktu dan tempat sesuai dengan hatga dan sumber anggaran yang dapat dipertanggungjawabkan. Kemudian dilanjutkan dengan pencatatan atau perbekalan, apakah barang tersebut berasal dari pembelian, hibah, hadiah. Setelah itu barang disimpan di gudang dan didistribusikan sesuai dengan analisis kebutuhan, dilakukan maintenance secara berkala dengan tujuan mempertahankan kondisi teknis, daya guna dan daya hasil serta menjamin kelangsungan usia pakai barang, sehingga bisa dimanfaatkan secara maksimal.

Dari studi pra penelitian yang terjadi dilapangan adalah pengelolaan manajemen perbekalan secara keseluruhan sudah mengandung tahapantahapan yang harus ada dalam pengelolaan perbekalan. Dari hasil wawancara pengelolaan perbekalan diawali dari adanya kegiata menyusun usulan barang-barang yang dibutuhkan selama satu tahun, yang meliputi abrang habis pakai dan barang tidak habis pakai. Kemudia setelah usulan di terima, maka akan disesuaikan dengan pagu anggaran, yang mana mengadaan bisa dilakukan dua kali dalam setahun. Ketika sudah disesuaikan dengan pagu anggaran maka rincian diserahkan kepada pihak ketiga atau disebut rekanan, yaitu pihak yang menyediakan barang. Setelah barang datang kemudian dilakukan pengecekan perihal kesesuaian barang yang dipesan dan apabila sudah sesuai maka akan dilakukan pecatatan ke dalam buku manual dan aplikasi SIMAK BMN oleh bagian akuntansi. Langkah selanjutnya barang yang sudah dicatat kemudian disimpan di gundang persediaan, 
rangkaian aktivitasnya akan berlanjut pada pendistribusian berdasarkan permintaan dengan dicatat ke dalam bon pengeluaran persediaan. Bon tersebut dibuat rangkap dua, satu disimpan oleh sub bagian umum dan sisanya di bagian akuntansi, untuk dicatat ke dalam aplikasi persediaan yang dinamai SIMAK BMN.

Pada kenyataanya dari hasil studi pra penelitian menunjukkan bahwa aktivitas perbekalan telah berjalan namun masih ada kesenjangan antara prosedur dengan praktik. Terjadi pemangkasan tahapan prosedur pengelolaan perbekalan, dimana tiap-tiap individu ketika membutuhkan barang-barang inventaris tidak sesuai standar operation procedure yang ditetapkan, kurang berjalannya pemakaian formulir-formulir perbekalan, belum ada petugas pergudangan khusus. Hasil penelitian menunjukkan masih ada permasalahan terkait dengan manajemen perbekalan. Permasalahan perbekalan yang paling mendasar adalah tidak terpenuhinya tenaga terampil dibidang manajemen perbekalan (Utami, 2012). Pengadaan barang-barang sulit, karena sistem pengadaan barang secara terpusat atau sentralisasi (Arifai, 2014). Kendala yang dihadapi dalam pengelolaan manajemen perbekalan adalah kurangnya sumber daya manusia (Atsari, 2013).

\section{METODOLOGI PENELITIAN}

Penelitian ini menggunakan pendekatan deskriptif kualitatif. Penelitian berfokus pada kegiatan perbekalan yang terdiri dari pengadaan, pencatatan, pendistribusian, penggudangan, pemeliharaan dan penghapusan. Lokasi penelitian dilaksanakan di Fakultas Ekonomi, Universitas Negeri Semarang. Menggunakan data primer dan data sekunder, dimana pengambilan data diperoleh dari informan (Kepala Tata
Usaha, Wakil Dekan Bidang Administrasi dan Keuangan, Kepala Bagian Sarana dan Prasaran, Petugas Gudang, Operator SIMAK BMN). Data juga diperoleh dari hasil observasi aktivitas perbekalan, dan analisis dokumen yang berkaitan dengan kegiatan perbekalan. Teknik pengumpulan data menggunakan wawancara mendalam, dokumentasi, observasi atau pengamatan dan analisis dokumen. Teknik pengambilan sampelnya adalah purposive sampling. Validitas data menggunakan teknik trianggulasi data atau sumber dan trianggulasi metodologis. Teknik analisis datanya menggunakan analisis interaktif. Data narasumber dan pengkodeannya bisa diamati pada tabel 1 .

Tabel 1. Informan di Fakultas Ekonomi, Universitas Negeri Semarang

\begin{tabular}{|c|l|l|}
\hline No. & \multicolumn{1}{|c|}{ Position } & \multicolumn{1}{c|}{ Code } \\
\hline 1. & Kepala Tata Usaha & K-TU \\
\hline 2. & $\begin{array}{l}\text { Kasubbag. Sarana } \\
\text { dan Prasarana }\end{array}$ & KSUB-UK \\
\hline 3. & Petugas Gudanag & PG \\
\hline 4. & $\begin{array}{l}\text { Operator SIMAK } \\
\text { BMN OS-BMN }\end{array}$ \\
\hline 5. & $\begin{array}{l}\text { Wakil Dekan Bidang } \\
\text { Administrasi dan } \\
\text { Keungan }\end{array}$ & WD-AU \\
\hline
\end{tabular}

\section{HASIL DAN PEMBAHASAN}

Implementasi pengelolaan perbekalan dapat dianalisis dari beberapa indikator, diantaranya: pengadaan, pencatatan, penyimpanan, pendistribusian, pemeliharaan dan penghapusan. Hasil analisis dari masing-masing indikator adalah sebagai berikut:

\section{Pengadaan}

Berdasarkan hasil wawacara dengan K-TU, prosedur pengadaan perbekalan dimulai dari pengajuan usulan pengadaan 
barang, yang selanjutnya akan diajukan ke pusat. Periode pengadaan barang-barang perbekalan baik itu barang inventaris maupun non inventaris dilakukan pada periode-periode yang sudah ditentukan. Barang inventaris yang tahan lama periode pengadaannya setiap 1 tahun sekali, sedangkan barang yang habis pakai seperti ATK (Alat Tulis Kantor) pengadaannya dilakukan setiap periode 4 bulan sekali.

\section{Pencatatan}

PG menyatakan bahwa seluruh pecatatan barang masuk maupun keluar baik itu barang persediaan maupun Barang Milik Negara (BMN) harus diserahkan kepada bagian Akuntansi untuk selanjutnya diinput ke dalam sistem. Selanjutnya OS-BMN mengatakan Idealnya saat barang persediaan keluar dari gudang harus segera dicatat oleh operator SIMAK BMN, namun realisasinya begitu barang keluar tidak segera dilaporkan operator SIMAK BMN. Sehingga sering dijumpai pencatatan pada sistem tidak sesuai dengan pencatatan pada buku persediaan manual. Kemudian, WD-AU mengungkapkan bahwa Barang Milik Negara seperti kursi pada tiap ruangan di catat dalam bentuk Daftar Inventaris Ruangan (DIR), hanya persoalannya jumlah ruangan sangat banyak, kemudian dalam banyak kasus barang-barang ini dipindahkan tidak terkontrol sehingga DIR menjadi tidak valid untuk masa-masa yang dinamis.

\section{Penyimpanan}

Fungsi gudang adalah sebagai tempat penyimpanan barang. Beberapa informan yaitu K-TU, KSUB-UK, PG, dan WD-AU menyatakan bahwa Fakultas Ekonomi memiliki 2 (dua) macam gudang, yaitu gudang persediaan dan gudang untuk barang rusak atau rongsokan. Namun ruang gudang jumlahnya terbatas, sehingga barang-barang yang rusak diletakkan pada area didepan kamar mandi dan bawah tangga. Selain itu untuk gudang persediaan, idealnya ada pemisahan antara gudang untuk barang berbentuk cair, padat dan mudah terbakar. Sistem penyimpanan menggunakan LIFO (Last In First Out) yaitu ketika barang masuk akan diletakkan paling atas, kemudian ketika dibutuhkan, barang paling atas yang akan diambil.

\section{Pemeliharaan}

Pemeliharaan diaplikasikan untuk menjaga nilai guna barang sesuai fungsinya. Berdasarkan informasi dari PG dan KSUB-UK, kegiatan pemeliharaan dilakukan saat barang mengalami kerusakan, atau pada saat awal perkuliahan setelah libur panjang. Sedangkan WD-AU dan K-TU menjelaskan pemeliharaan dilakukan setiap 4 bulan sekali.

\section{Penghapusan}

WD-AU dan K-TU mengungkapkan bahwa barang rusak yang diusulkan untuk dihapuskan sejak 2 sampai 3 tahun yang lalu belum dimusnahkan, sehingga mengalami penumpukkan.

\section{A. Implementasi Pengelolaan perbekalan di Fakultas Ekonomi UNNES}

\section{Pengadaan}

Kegiatan pengadaan dilakukan dengan cara pembelian, meskipun seringkali barang inventaris juga diperoleh dari hibah dan hadiah. Berdasarkan hasil wawancara dengan KTU pengadaan barang perbekalan yang habis pakai dilakukan setiap 4 bulan sekali, dan barang tahan lama setiap 1 tahun sekali. Hal ini sesuai dengan pernyataan PG yang mengatakan bahwa 
stock opname barang perlengkapan kantor dilakukan sertiap 4 bulan sekali. Hasil observasi dan dokumen mengungkapkan hal yang sama.

\section{Pencatatan}

Wawancara dengan PD,OS-BMN, dan WD-AU menyatakan bahwa egiatan pencatatan dilakukan dengan 2 cara yaitu secara manual dan secara sistem. Dari hasil observasi memang benar kegiatan pencatatan dilakukan dengan kedua sistem tesebut. Petugas Gudang selalu mencatat barang-barang yang masuk ke dalam buku manual kemudian selanjutnya diteruskan kepada Operator SIMAK BMN untuk diinput pada sistem. Pencatatan barang perbekalan cukup baik dibuktikan dengan dimilikinya Buku Persediaan Barang, Formulir Pemakaian Barang, dan penggunaan sistem SIMAK BMN.

\section{Penyimpanan}

K-TU, KSUB-UK, PG, dan WD-AU menyatakan bahwa gudang penyimpanan dibedakan menjadi gudang persediaan dan gudang barang rongsokan. Berdasarkan hasil pengamatan kedua gudang tersebut letaknya terpisah. Gudang persediaan terletak di Gedung C6 latai 2 sedangkan gudang barang tidak terpakai atau rusak di Gedung C3 lantai 2 dan 3. Penataan gudang belum ideal, karena tidak ada pemisahan antara barang yang sifatnya cairan maupun padat.

\section{Pemeliharaan}

WD-AU dan K-TU menjelaskan bahwa pemeliharaan dilakukan terjadwal yaitu 3 kali dalam satu tahun. namun pada kenyataannya hanya ketika barang rusak saja yang dilakukan perawatan/pemeliharaan. Cek list perawatan barang inventaris diruangruang tidak menunjukkan adanya perawatan secara berkala.

\section{Penghapusan}

Prosedur penghapusan dilakukan secara sentralisasi, yaitu dilakukan oleh pusat atas persetujuan Kementerian Riset dan Tekonogi Pendidikan Tinggi (KEMENRISTEK DIKTI) sehingga membutuhkan waktu lama untuk penghapusannya (WD-AU dan PG).

\section{B. Hambatan Pelaksanaan Pengelolaan Perbekalan}

\section{Sumber daya manusia terampil}

Menurut pernyataan PG, ia menyadari kegiatan perbekalan yang selama ini berjalan tidaklah ideal, ia hanya menjalankan apa yang ia ketahui. PG menyatakan ia bekerja pada bagian sarana dan prasarana yang mengurusi kebutuhan rumah tangga organisasi, namun ia juga merangkap sebagai petugas gudang. Hal tersebut diperkuat dengan pendapat WD-AU yang menyatakan bahwa belum ada petugas gudang khusus, kita hanya mengambil satu pegawai dari bagian sarana dan prasarana untuk diperbantukan menata dan mengelola barang-barang digudang. Hal ini diperkuat dengan dokumen kepegawaian yang mendeskripsikan bahwa PG adalah lulusan sarjana Pendidikan Akuntansi, sehingga keilmuan yang ia miliki tidak sesuai dengan pekerjaan yang sekarang ini ia tekuni.

2. Kontrol barang inventaris baik dari segi pencatatan, penggudangan, pemeliharaan dan penghapusan.

Barang inventaris merupakan barang milik negara yang usia pakainya lebih dari satu tahun dan dicatat dalam buku inventaris. WD-AU menyatakan bahwa disetiap ruang terdapat DIR (Daftar Inventaris Ruangan), pernyataan yang sama juga dilontarkan oleh PG 
menjelaskan bahwa DIR berada disetiap ruangan, bentuknya berupa kartu, yang berisi informasi tentang jenis dan jumlah barang inventaris. Akan tetapi terkadang DIR tidak diupdate. Dibuktikan dengan banyak ruangan yang tidak terdapat Kartu DIR. Begitu juga dengan pemeliharaan barang-barang inventaris juga belum terkontrol, berdasarkan hasil wawancara dengan WD-AU, K-TU dilakukan secara terjadwal 3 kali dalam satu tahun, berbeda dengan kondisi dilapangan, barang-barang inventaris seperti AC dan kipas angin tidak berfungsi secara maksimal. Barangbarang tersebut diperbaiki hanya ketika rusak atau bahkan tidak diperbaiki.

Penyimpanan barang-barang inventaris disimpan di gudang persediaan dan gudang barang bekas, pernyataan tersebut dikemukakan oleh K-TU, KSUB-UK, PG, dan WD-AU. Barang-barang inventaris yang sudah siap untuk dihapuskan disimpan di gudang barang bekas, akan tetapi karena kekurangan ruang gudang maka disimpan pada ruang-ruang yang kosong, seperti depan kamar mandi dan bawah tangga. Kondisi ini disebabkan karena sistem penghapusan barang secara terpusat, sehingga setiap barang yang akan dihapuskan harus menunggu persetujuan pusat yaitu KEMENRISTEK DIKTI.

\section{PENUTUP}

\section{Kesimpulan}

Berdasarkan analisis terhadap hasil wawancara dan pengamatan terhadap serangkaian proses perbekalan yang berlangsung di Fakultas Ekonomi Universitas Negeri Semarang, hasil penelitian dan pembahasan dapat ditarik kesimpulan sebagai berikut :
1. Pengelolaan perbekalan yang berlaku pada Fakultas Ekonomi Unnes terdiri dari serangkaian tahapan yang kompleks dengan kebutuhan sumber daya manusia yang tidak sedikit. Tahapan tersebut yaitu pengadaan, pencatatan, penggudangan/penyimpanan, pemeliharaan, penghapusan.

2. Kendala yang dihadapi dalam kegiatan penggudangan di Fakultas Ekonomi Unnes dilatarbelakangi oleh keterbatasan sumber daya manusia yang ada. Kendala keterbatasan petugas gudang dijumpai pada serangkaian aktivitas, pencatatan, penyimpanan dan perawatan barang tidak terkontrol.

a. Keterampilan petugas pengelola perbekalan belum memmenuhi spesifikasi kegiatan pengurusan perbekalan.

b. Pencatatan tidak terkontrol, seperti Daftar Inventaris Ruang (DIR) tidak disesuaikan dengan kondisi dimasing-masing tuang

c. Pencatatan barang inventaris yang dilakukan oleh petugas gudang terkadang tidak sama dengan yang dicatat oleh operator SIMAK BMN
d. Pemelihataan barang tidak dilakukan secara berkala dan terjadwal,

\section{Saran}

Berdasarkan simpulan di atas yang dapat disarankan dari peneliti adalah :

1. Pelatihan dan pendampingan bagi petugas gudang secara berkesinambungan.

2. Pengecekan dan pemutakhiran data DIR, buku induk barang inventaris dan SIMAK BMN harus dilakukan terjadwal dan setiap ada pengurangan dan penambahan barang logistik. 
3. Pemelihataan barang dilakukan setiap satu bulan sekali guna meminimalisir terjadinya kerusakan barang inventaris.

\section{REFERENSI}

[1] Arifai, R., Roeliana, L., \& Suharto, S. (2014). ANALISIS MANAJEMEN PERBEKALAN ALAT-ALAT KESEHATAN PADA RUMAH SAKIT TINGKAT IV DETASEMEN KESEHATAN WILAYAH 02.07. 01 KOTA BENGKULU (Doctoral dissertation, Universitas Bengkulu).

[2] Astari, R. (2013). Manajemen pengelolaan inventarisasi guna menunjang aktivitas perbekalan di program pasca sarjana universitas negeri semarang (Doctoral dissertation, Universitas Negeri Semarang).

[3] Bowersox, Donald J. 2009. Manajemen Logistik Intergrasi Sistem-Sistem Manajemen Distribusi Fisik dan Manajemen Material. Jakarta: Bumi Aksara.

[4] Dwiantara, Lukas dan Rumsari Hadi Sumarto.2004.Manajemen Logistik Pedoman Praktis Bagi Sekretaris dan Staf Administrasi. Jakarta: Grasindo.
[5] Dwiantara, Lukas dan Rumsari Hadi Sumarto.2009. Manajemen Logistik Pedoman Praktis Bagi Sekretaris dan Staf Administrasi. Jakarta: Grasindo.

[6] Gitosudarmo, Indriyo. 2000. Perilaku Pengorganisasian. Yogjakarta : BPFE.

[7] Hasibuan, Malayu S.P. 2003. Manajemen Dasar, Pengertian, dan Masalah. Jakarta: Bumi Aksara

[8] Moh, Nazir. 1999. Metode Penelitian. Jakarta : Ghalia Indonesia.

[9] Moleong, Lexy. J. 2006. Metodologi Penelitian Kualitatif. Bandung: Remaja Rosda Karya.

[10] Murwaningsih, Tri. 2005. Ilmu Administrasi. Surakarta : FKIP UNS.

[11] Richardus Eko, Richardus Djokopraptono.2003. Manajemen Persediaan. Jakarta : PT. Grasindo.

[12] Robbins, Stephen P dan Mary Coulter. 2010. Manajemen. Terjemahan Bob Sabran, M.M dan Devri Barnadi Putera. Jakarta: Erlangga.

[13] Sugiyono. 2008. Memahami Penelitian Kualitatif. Bandung: CV. Alfabeta

[14] Utami, N. A. P., Wagimin, I., \& Widodo, J. (2012). Manajemen Perbekalan Kantor Palang Merah Indonesia. - . 